\title{
Experimental Study on the Pathological Changes in Lung Tissue Caused by Zinc Stearate Dust
}

\author{
Atsushi UEDA*, Koichi HARADA**, Tadako UEDA* and \\ Shigeru NOMURA ${ }^{* * *}$ \\ * Department of Hygiene, Faculty of Medicine, Kagoshima University, \\ 1208-1, Usuki-cho, Kagoshima City, Kagoshima 890, Japan \\ ** Department of Hygiene, Kumamoto University Medical School, \\ 2-2-1, Honjo, Kumamoto City, Kumamoto 860, Japan \\ *** Department of Public Health, Kumamoto University Medical School, \\ 2-2-1, Honjo, Kumamoto City, Kumamoto 860, Japan
}

(Received June 27, 1984 and in revised form August 24, 1984)

\begin{abstract}
Pathological changes in lung tissues of Sprague Dawley rats after single intratracheal administration of $1 \mathrm{mg}, 5 \mathrm{mg}$ or $10 \mathrm{mg}$ of zinc stearate were examined to ascertain whether lung fibrosis such as that described in Uotila's case report is caused by exposure to this dust.

The results obtained were as follows:

1. The lungs of rats administered 1-10 $\mathrm{mg}$ of zinc stearate did not show any evident formation of dust foci or proliferation of collagen fibers after nine months, whereas such changes were evident in the rats administered $10 \mathrm{mg}$ of quartz.

2. The hydroxyproline content of the lung, as an indicator of collagen fiber formation, was significantly less in the zinc stearate groups than in the rats administered $10 \mathrm{mg}$ of quartz.

3. The $\mathrm{Zn}$ content of the lung tissues increased soon after the administration of the dust and then decreased rapidly. The incresed dust content of whole lungs of rats administered $10 \mathrm{mg}$ of zinc stearate was $641 \mu \mathrm{g}$ after week and $53 \mu \mathrm{g}$ after nine months.

From the above results, it was considered that zinc stearate by itself might not always act as a severe chemical irritant or a main facter in fatal pneumoconiosis.

Key words: Pneumoconiosis-Zinc stearate dust-Fibrogenecity-Hydroxyproline -Quartz
\end{abstract}

\section{INTRODUCTION}

Zinc stearate $\left[\left(\mathrm{CH}_{3}\left(\mathrm{CH}_{2}\right)_{16} \mathrm{C} / \mathrm{O}\right)_{2} \mathrm{Zn}\right]$, molecular weight 632.30 , is a white, water-insoluble powder, and is used widely in such industries as cosmetic, pharmaceutical, rubber lubricant and metal stabilizer, with a yearly production in Japan of $6000-6500$ tons, 
As for the toxicity of this substance, in 1926 Murray reported three infantile cases, including one fatal case, of a diffuse bronchopneumonia resulting from the accidental aspiration of zinc stearate powder. ${ }^{1)}$ Uotila et al. described a fatal case of a rubber industry worker employed for 29 years involving extensive lung fibrosis with positive $\mathrm{Zn}$ retention in the granulomatous tissues. ${ }^{2)}$ From such reports, zinc stearate has been regarded as a severe chemical irritant, causing progressive pneumonitis or fatal pneumoconiosis. ${ }^{3,4}$ However, at present there are no conclusive reports in regard to whether lung fibrosis is related to the occupational inhalation of zinc stearate powder, and Uotila's observations have not yet been confirmed experimentally.

The purpose of this paper is to confirm findings in Uotila's case experimentally and to obtain further detailed information on pathological changes in the lung tissue due to administration of zinc stearate powder.

\section{MAterials AND Methods}

Zinc stearate, a reagent from Nakarai Chemicals Ltd. (Japan) with a $70 \%$ zinc stearate content, and quartz from Mt. Shodai in Kumamoto Prefecture, kindly provided by Prof. H. Yamada, Kumamoto University Technical School, were used. The samples were ground in a ball mill, with a final particle size range of $1-5 \mu$ in diameter (Fig. 1-a, b). The grinding time for zinc stearate was less than six hours so as not to damage the physical properties and the structure of the particulates. The samples were suspended in $10 \%$ alcohol solution, because zinc stearate cannot be suspended well with physiological saline or distilled water.

A total of 71 4-month-old Sprague Dawley male rats, weighing 250-300 g, were divided into seven groups of six to 23 rats each. One $\mathrm{m} l$ of the suspended sample mixed with 2000 IU of penicillin G potassium were administered once intratrachealy according to the method of King et al. ${ }^{5)}$ The dose for each group was as follows:

Groups I, II, III: 1,5 and $10 \mathrm{mg}$ of zinc stearate/rat, respectively;

Groups IV, V: 1 and $10 \mathrm{mg}$ of quartz/rat, respectively;

Group VI: only $1 \mathrm{ml}$ of $10 \%$ alcohol solution;

Group VII: nothing was given.

Because of the physical properties of zinc stearate, namely water-insolubility, low specific gravity and cohesiveness in solution, it was difficult to administer zinc stearate powder in to the rats lung at concentrations over $10 \mathrm{mg} / \mathrm{rat} / \mathrm{ml}$. A dose of $10 \mathrm{mg}$ of quartz was estimated to be the smallest dose to cause evident dust foci in the lungs.

The animals were housed in an air-conditioned room at $24 \pm 1{ }^{\circ} \mathrm{C}$ and were allowed free access to pellets and water. They were sacrificed at the end of nine months after the injection. Six animals of Group III and three of Group VII were killed soon after the injection. Five animals of Group III and three of 


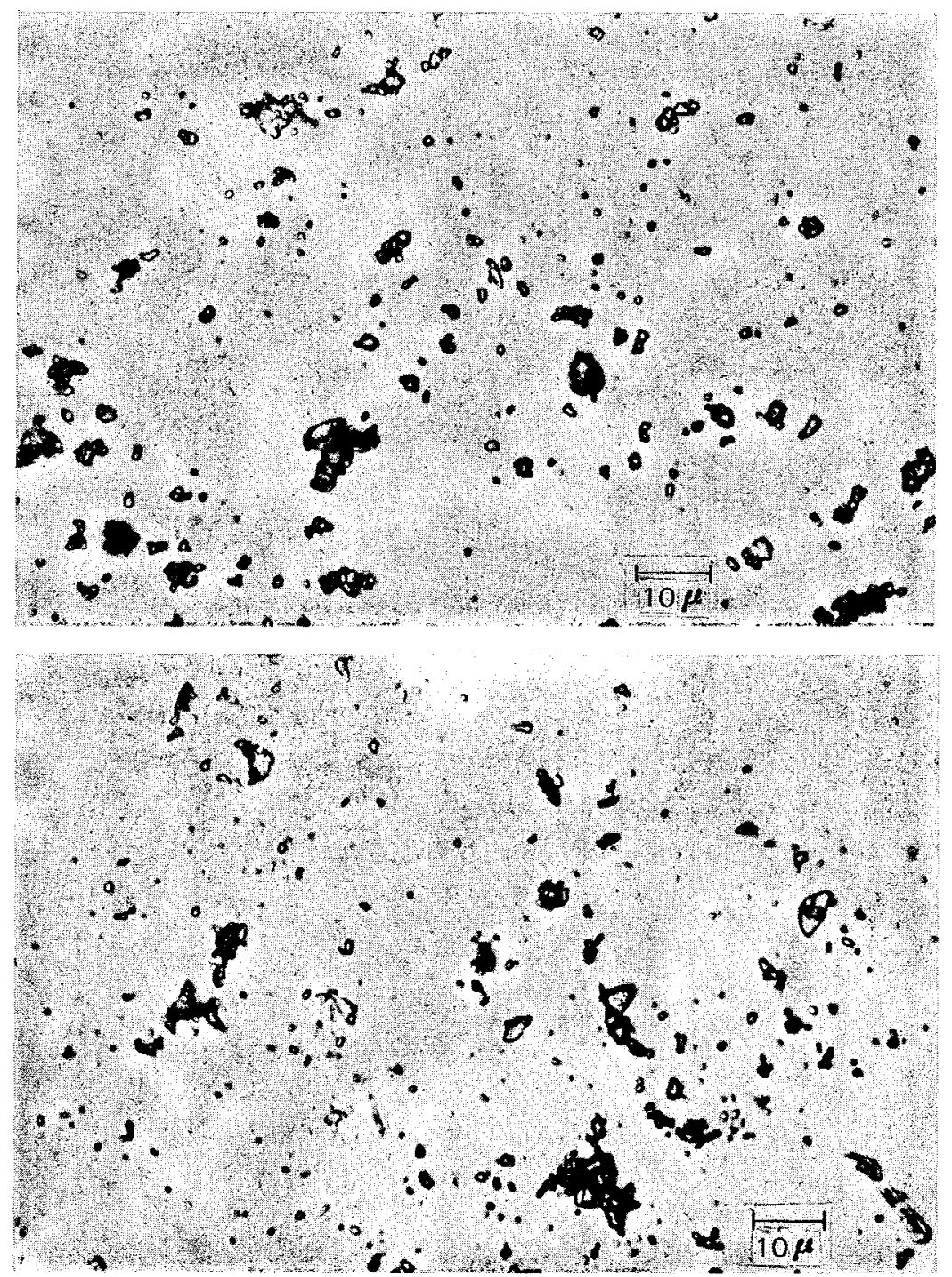

[a]

Fig. 1. Dust for administration

[a] Zinc stearate

[b] Quartz

Group V were killed one week after the injection.

The lungs were removed and fixed with $10 \%$ buffered formalin. The left lung was used for histological examination, and the right one for chemical analysis. The mediastinal lymph nodes and the liver were also examined. After the usual dehydration and embedding, a slice of the left lung was stained with hematoxylineosin, silver and Van Gieson's method. Thirty $\mathrm{mg}$ of dried tissue of the right lung, after being hydrolyzed at $140^{\circ} \mathrm{C}$ by $6 \mathrm{~N} \mathrm{HCl}$ for 10 hours, was assayed 
for hydroxyproline (HOP) according to the method of Stacy et al. ${ }^{6)}$ and Kivirikko et al. ${ }^{7)}$ The residue of $100-200 \mathrm{mg}$ of dried tissue was wet-ashed by conc- $\mathrm{HNO}_{3}$, $\mathrm{H}_{2} \mathrm{SO}_{4}$ and $\mathrm{HClO}_{4}$ in turn with heating, and $\mathrm{Zn}$ was determined by atomic absorption spectrometry. ${ }^{8}$ In this method, the percentage of recovery was $97.2 \pm 30.0(\mathrm{~N}=9)$.

The concentrations $(\mu \mathrm{g} / \mathrm{mg}$ of dried tissue) of HOP and $\mathrm{Zn}$ were converted to total lung content by the following formula:

$\mathrm{Y}$ (HOP or $\mathrm{Zn}$ content in total lung) $=$ Concentration in dried tissue $\times$ Dried weight of right lung $(\mathrm{g}) \times \frac{\text { Wet weight of the total lung }(\mathrm{g})}{\text { Wet weight of the right lung }(\mathrm{g})}$

\section{Results}

\section{Macroscopic changes:}

The average weight of the lungs tended to be greater in the quartz-treated groups (IV, V) than in the zinc stearate groups (I, II, III) (Table 1).

As shown in Table 2, nine months after the injection there was no nodular formation through the surface of the lungs of Groups I, II and III administered $1-10 \mathrm{mg}$ of zinc stearate. In contrast, a relatively large number of scattered dust foci were seen in the lungs or Group V. However, pneumonia or a reddening

Table 1. Wet weights of lung, thymus and liver nine months after the injection

$\mathrm{M} \pm \mathrm{SD}$

\begin{tabular}{|c|c|c|c|c|}
\hline \multirow{2}{*}{ Kind of dust } & \multirow{2}{*}{$\begin{array}{l}\text { No. of } \\
\text { animals }\end{array}$} & \multicolumn{3}{|c|}{ Organs } \\
\hline & & Lung & Thymus & Liver \\
\hline \multicolumn{2}{|l|}{ Zinc stearate } & $\mathrm{g}(\mathrm{g} / \mathrm{kg})$ & $\mathrm{g}(\mathrm{g} / \mathrm{kg})$ & $\mathrm{g}(\mathrm{g} / \mathrm{kg})$ \\
\hline Group I: $1 \mathrm{mg}$ & 6 & $\begin{array}{l}2.24 \pm 0.30^{* *} \\
(3.38 \pm 0.83)\end{array}$ & $\begin{array}{c}0.10 \pm 0.04 \\
(0.16 \pm 0.06)\end{array}$ & $\begin{array}{c}20.4 \pm 1.3 \\
(31.8 \pm 2.3)^{a}\end{array}$ \\
\hline Group II: $5 \mathrm{mg}$ & 6 & $\begin{array}{c}2.59 \pm 0.46 \\
(3.83 \pm 0.82)\end{array}$ & $\begin{array}{c}0.08 \pm 0.02 \\
(0.12 \pm 0.03)\end{array}$ & $\begin{array}{c}20.0 \pm 2.4 \\
(29.2 \pm 2.5)\end{array}$ \\
\hline Group III : $10 \mathrm{mg}$ & $12[1]^{\mathrm{b}}$ & $\begin{array}{c}2.43 \pm 0.48 * \\
(3.59 \pm 0.79)\end{array}$ & $\begin{array}{c}0.09 \pm 0.03 \\
(0.14 \pm 0.06)\end{array}$ & $\begin{array}{c}21.3 \pm 4.0 \\
(30.4 \pm 2.8)\end{array}$ \\
\hline \multicolumn{5}{|l|}{ Quartz } \\
\hline Group IV: $1 \mathrm{mg}$ & 6 & $\begin{array}{c}2.53 \pm 0.41 \\
(3.98 \pm 0.83)\end{array}$ & $\begin{array}{c}0.09 \pm 0.02 \\
(0.13 \pm 0.04)\end{array}$ & $\begin{array}{c}18.7 \pm 1.9^{*} \\
(29.1 \pm 1.3)\end{array}$ \\
\hline Group $\quad \mathrm{V}: 10 \mathrm{mg}$ & $12[1]$ & $\begin{array}{c}2.97 \pm 0.50 \\
(4.15 \pm 1.08)\end{array}$ & $\begin{array}{c}0.09 \pm 0.04 \\
(0.13 \pm 0.05)\end{array}$ & $\begin{array}{c}22.3 \pm 3.2 \\
(30.6 \pm 3.2)\end{array}$ \\
\hline \multicolumn{5}{|l|}{$10 \%$ Alcohol } \\
\hline Group VI: $1 \mathrm{~m} l$ & 6 & $\begin{array}{c}2.49 \pm 0.67 \\
(3.85 \pm 1.12)\end{array}$ & $\begin{array}{c}0.12 \pm 0.05 \\
(0.15 \pm 0.06)\end{array}$ & $\begin{array}{c}20.4 \pm 2.7 \\
(31.5 \pm 3.7)\end{array}$ \\
\hline \multicolumn{5}{|l|}{ No treatment } \\
\hline Group VII : & 6 & $\begin{array}{c}2.45 \pm 0.36 \\
(3.66 \pm 0.63)\end{array}$ & $\begin{array}{c}0.08 \pm 0.04 \\
(0.12 \pm 0.04)\end{array}$ & $\begin{array}{c}21.6 \pm 3.1 \\
(33.1 \pm 3.0)\end{array}$ \\
\hline
\end{tabular}

** $\mathrm{p}<0.01 * \mathrm{p}<0.05$ : Significance between Group V and each other group [t-test]

t† $\mathrm{p}<0.01 \dagger \mathrm{p}<0.05$ : Significance between Group IV and each other group [t-test]

a Wet weights per $\mathrm{kg}$ of body weight in parantheses

b No. of deaths during nine months 
change was more common in the lungs of the zinc stearate groups than the quartz groups. Swelling of the mediastinal lymph nodes was less obvious in the zinc stearate groups than in the quartz groups.

The lungs of Group VI administered alcohol and Group VII as controls were almost normal.

Microscopic changes:

A summary of the histological changes is shown in Table 2 . No evident dust foci or lymphocytic granulomatous lesions were found in the lungs of the zinc stearate groups (Fig. 2-a, b). In contrast, the lungs in the 10-mg quartz group contained well-defined cellular-rich nodules, with moderate proliferation of collagen fibers (Fig. 3-a, b). Such silicotic lesions were not so clear in the lung of the 1-mg quartz group.

The thickening of intra-alveolar septa, moderately proliferating reticulin fibers and/or overdistention of alveoli were generally found in the lungs of the zinc stearate groups, as well as in the quartz groups. In the mediastinal lymph nodes, no change was found in the zinc stearate groups, while distinct fibrous proliferation was observed in the 10-mg quartz group.

Table 2. Pathological changes in rat lungs nine months after intratracheal injection

\begin{tabular}{|c|c|c|c|c|c|c|c|c|c|}
\hline \multirow{3}{*}{ Findings } & \multirow{3}{*}{\multicolumn{2}{|c|}{ (dose/rat) }} & \multicolumn{7}{|c|}{ Kind of dust } \\
\hline & & & \multicolumn{3}{|c|}{ Zinc stearate } & \multicolumn{2}{|c|}{ Quartz } & \multirow{2}{*}{$\begin{array}{c}10 \% \\
\text { Alcohol } \\
1 \mathrm{ml}\end{array}$} & \multirow{2}{*}{$\begin{array}{l}\text { No } \\
\text { treat- } \\
\text { ment }\end{array}$} \\
\hline & & & $10 \mathrm{mg}$ & $5 \mathrm{mg}$ & $1 \mathrm{mg}$ & $10 \mathrm{mg}$ & $1 \mathrm{mg}$ & & \\
\hline \multirow{4}{*}{$\begin{array}{l}\text { Macroscopic } \\
\text { findings of } \\
\text { lung }\end{array}$} & \multirow{4}{*}{\multicolumn{2}{|c|}{$\begin{array}{l}\text { Pleural adhesion } \\
\text { Hemorrhage } \\
\text { Hepatization } \\
\text { Dust foci through } \\
\text { pleura }\end{array}$}} & \pm & - & \pm & \pm & - & - & - \\
\hline & & & + & \pm & \pm & \pm & \pm & \pm & \pm \\
\hline & & & \pm & \pm & \pm & \pm & - & \pm & \pm \\
\hline & & & - & - & - & + & \pm & - & - \\
\hline \multirow{10}{*}{$\begin{array}{l}\text { Microscopic } \\
\text { findings in } \\
\text { lung }\end{array}$} & \multicolumn{2}{|c|}{ Dust retention } & \pm & - & - & $+*$ & \pm & - & - \\
\hline & \multirow{4}{*}{$\begin{array}{l}\text { Dust } \\
\text { foci }\end{array}$} & Macrophage & \pm & \pm & - & $+^{*}$ & \pm & - & - \\
\hline & & Giant cell & - & - & - & \pm & - & - & - \\
\hline & & Fibroblast & - & - & - & + & \pm & - & - \\
\hline & & Fibrosis & - & - & - & $+*$ & \pm & - & - \\
\hline & \multirow{4}{*}{$\begin{array}{l}\text { Changes } \\
\text { in lung } \\
\text { tissue }\end{array}$} & Atelectasis & \pm & \pm & \pm & $+*$ & \pm & \pm & - \\
\hline & & Emphysema & + & \pm & \pm & $t^{*}$ & + & - & - \\
\hline & & Pneumonia & + & \pm & \pm & + & \pm & \pm & \pm \\
\hline & & Abscess & + & \pm & \pm & + & \pm & \pm & \pm \\
\hline & \multicolumn{2}{|c|}{ Changes in bronchs } & + & + & \pm & $+*$ & + & \pm & - \\
\hline Findings in & ylar lymp & h node & - & - & - & $t^{*}$ & \pm & - & - \\
\hline
\end{tabular}

- No animals developing a corresponding change

\pm Under $50 \%$ of animals developing a corresponding change

+ Over $50 \%$ or more animals developing a corresponding change

* Showing severe and/or wide extent of lesions 

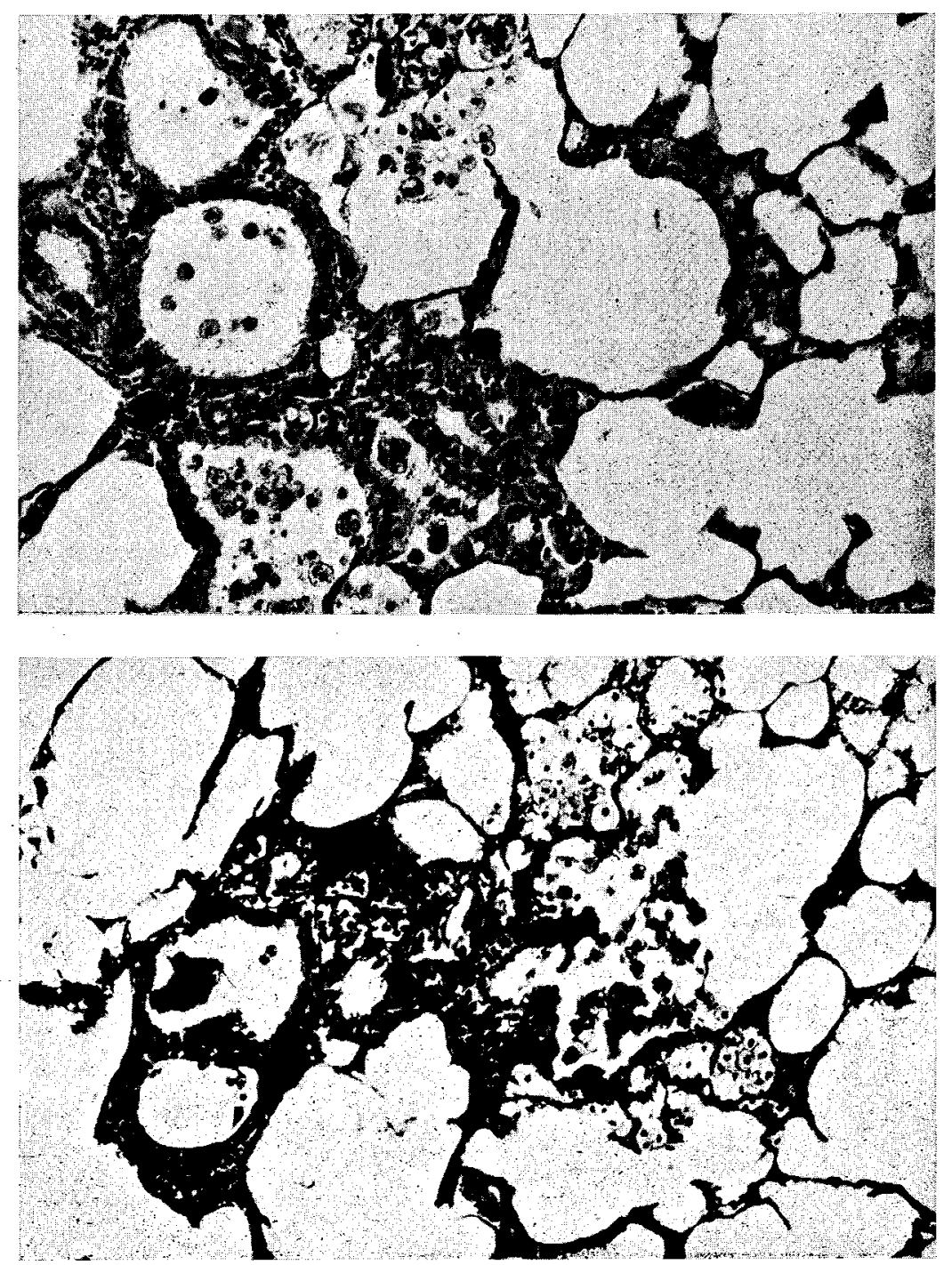

Fig. 2. Rat lung nine months after administration of $10 \mathrm{mg}$ of zinc stearate Moderate inflammatory reactions of bronchioles and overdistention of surrounding alveoli.

[a] Stained with hematoxylin-eosin

[b] Stained with silver

One week after the injection, the lungs of Groups III (10 mg of zinc stearate) and V (10 mg of quartz) were congested and extensive interstitial cellular infiltration was found as a result of the injection of the dust. The intensity of the inflammatory reaction was somewhat more severe in the quartz groups than in the zinc stearate groups. 

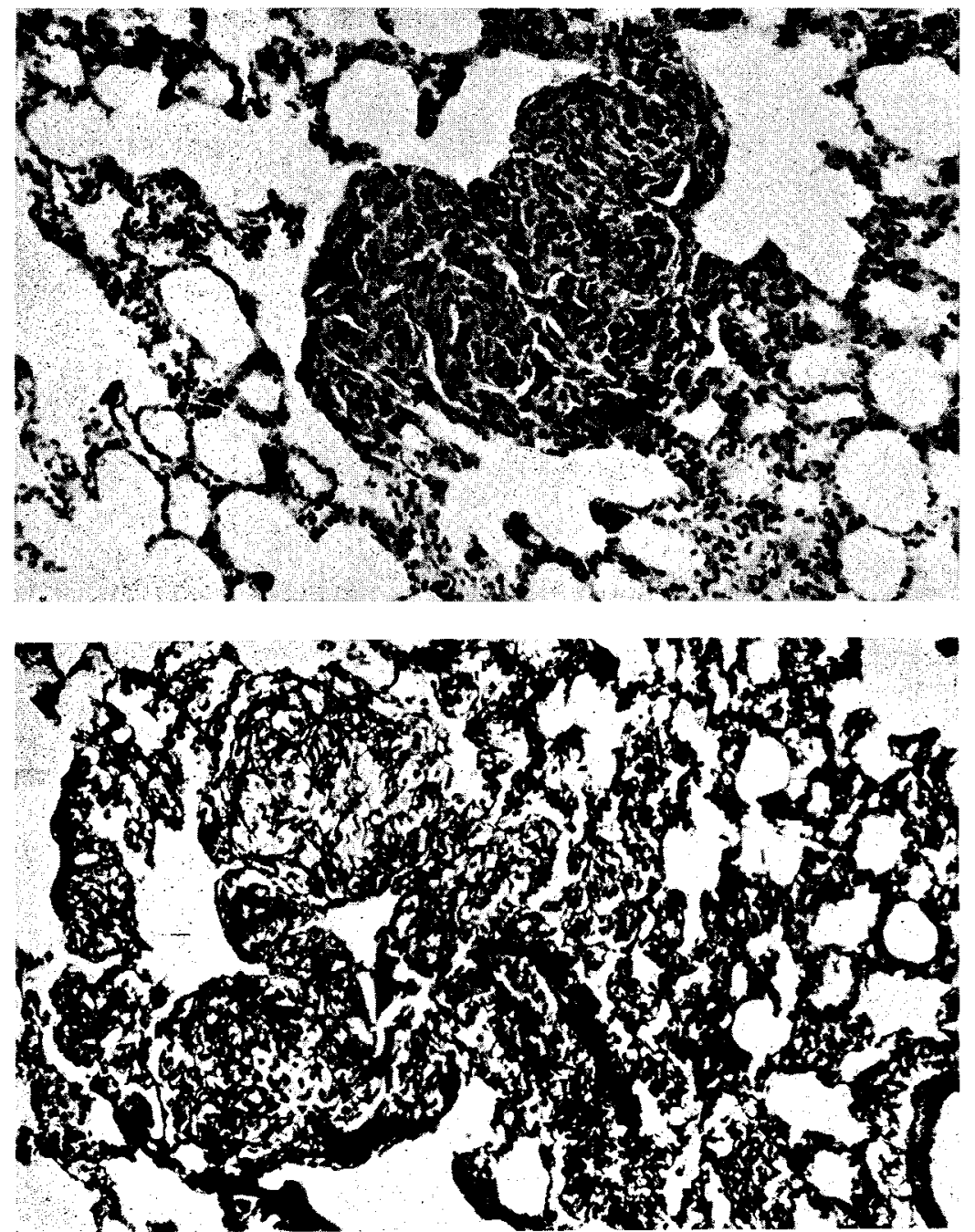

Fig. 3. Rat lung nine months after administration of $10 \mathrm{mg}$ of quartz Dust foci, filling alveoli with lymphocytes and fibroblasts.

[a] Stained with hematoxylin-eosin

[b] Stained with silver

Hydroxyproline content of the lung tissue:

The 10-mg quartz group showed the highest average HOP content of the lung tissues $(p<0.01-0.05)$. The values in the $1-\mathrm{mg}$ quartz group were slightly higher than those in the zinc stearate groups, but there was no significant difference between them (Table 3 ).

Zn content of the lung tissue:

Higher zinc concentrations per milligram of dried tissue and total lung content 
Table 3. Hydroxyproline and $\mathrm{Zn}$ content of whole lungs ${ }^{\mathrm{a}}$

$\mathrm{M} \pm \mathrm{SD}$

\begin{tabular}{|c|c|c|c|c|}
\hline Kind of dust & $\begin{array}{c}\text { Time of sacrifice } \\
\text { after the } \\
\text { administration }\end{array}$ & $\begin{array}{l}\text { No. of } \\
\text { animals }\end{array}$ & $\begin{array}{l}\text { Hydroxyproline } \\
(\text { HOP })\end{array}$ & $\mathrm{Zn}$ \\
\hline \multicolumn{3}{|c|}{ Zinc stearate } & $\mathrm{mg}(\mu \mathrm{g} / \mathrm{mg})$ & $\mathrm{mg}(\mu \mathrm{g} / \mathrm{mg})$ \\
\hline Group $\quad$ I : & nine months & 3 & $\begin{array}{c}3.99 \pm 0.80^{* *} \\
(10.7 \pm 2.5)^{b}\end{array}$ & $\begin{array}{c}69 \pm 9 * *+t \\
(0.192 \pm 0.008)^{* * \dagger t}\end{array}$ \\
\hline Group & nine months & 6 & $\begin{array}{c}4.02 \pm 0.70^{*} \\
(10.4 \pm 3.0)\end{array}$ & $\begin{array}{c}84 \pm 18 * *+ \\
(0.208 \pm 0.028)^{* *+\dagger}\end{array}$ \\
\hline \multirow[t]{3}{*}{ Group } & nine months & 11 & $\begin{array}{l}4.21 \pm 0.93^{* *} \\
(11.4 \pm 2.7)\end{array}$ & $\begin{array}{c}92 \pm 25^{* *+\dagger} \\
(0.227 \pm 0.041)^{* *+\dagger}\end{array}$ \\
\hline & one week & 5 & $\begin{array}{l}2.08 \pm 0.34 * *+\dagger \\
(8.3 \pm 1.8) * \dagger\end{array}$ & $\begin{array}{c}217 \pm 138 * * \pi \\
(0.890 \pm 0.461)^{* *+t}\end{array}$ \\
\hline & soon after & 6 & $\begin{array}{l}1.63 \pm 0.20^{* *+\dagger} \\
(6.6 \pm 0.6)^{* * \dagger \dagger}\end{array}$ & $\begin{array}{c}679 \pm 250 * *+t \\
(2.743 \pm 0.950) * *+t\end{array}$ \\
\hline \multicolumn{5}{|l|}{ Quartz } \\
\hline Group & nine months & 6 & $\begin{array}{c}4.69 \pm 0.58 \\
(13.2 \pm 2.4)\end{array}$ & $\begin{array}{c}41 \pm 10 \\
(0.112 \pm 0.012)\end{array}$ \\
\hline \multirow[t]{2}{*}{ Group } & nine months & $10^{c}$ & $\begin{array}{c}6.17 \pm 1.70 \\
(13.8 \pm 3.1)\end{array}$ & $\begin{array}{c}46 \pm 9 \\
(1.102 \pm 0.008)\end{array}$ \\
\hline & one week & 3 & $\begin{array}{l}2.48 \pm 0.26 \\
(8.5 \pm 1.9)\end{array}$ & $\begin{array}{c}47 \pm 14 \\
(0.164 \pm 0.006)\end{array}$ \\
\hline \multicolumn{5}{|c|}{$10 \%$ Alcohol } \\
\hline Group VI: & nine months & 6 & $\begin{array}{l}4.10 \pm 0.82^{*} \\
(11.4 \pm 2.1)\end{array}$ & $\begin{array}{c}42 \pm 13 \\
(0.111 \pm 0.005)\end{array}$ \\
\hline \multicolumn{5}{|c|}{ No treatment } \\
\hline \multirow[t]{2}{*}{ Group VII : } & nine months & 6 & $\begin{array}{l}3.68 \pm 0.76^{* *+\dagger} \\
(10.4 \pm 3.0)\end{array}$ & $\begin{array}{c}38 \pm 9 \\
(0.107 \pm 0.008)\end{array}$ \\
\hline & soon after & 3 & $\begin{array}{l}1.48 \pm 0.62^{* *+\dagger} \\
(5.0 \pm 2.0)^{* *+t}\end{array}$ & $\begin{array}{c}38 \pm 6 \\
(0.125 \pm 0.000)\end{array}$ \\
\hline
\end{tabular}

** $\mathrm{p}<0.01 * \mathrm{p}<0.05$ : Significance between group $\mathrm{V}$, nine months, and each other group [t-test]

tt $\mathrm{p}<0.01+\mathrm{p}<0.05$ : Significance between group IV, nine months, and each other group [t-test]

a Converted to the total lung content for each by the following formula:

$\mathrm{Y}$ (HOP or $\mathrm{Zn}$ content of total lungs)=Concentration $(\mu \mathrm{g} / \mathrm{mg})$ in dried tissue $\mathbf{X}$ Dried weight of the right lung $(\mathrm{g}) \mathrm{X}$

Wet weight of the total lung (g)/Wet weight of the right lung (g)

b Concentration per $\mathrm{mg}$ of dried tissue in parentheses

c One sample out of 11 animals was mis-determined and excluded from the table

were observed in the 1- to 10-mg zinc stearate groups than in the quartz and other control groups $(\mathbf{P}<0.01-0.05)$ (Table 3$)$. The difference between the amounts in the control group and those in the zinc stearate group was assumed to be the amount of deposited zinc resulting from zinc stearate administration. Therefore, the excess of $30-50 \mu \mathrm{g}$ of $\mathrm{Zn}$ in the $1-$ to $10-\mathrm{mg}$ zinc stearate groups nine months after the injection was thought to have been retained from the initial dose. The retention of $\mathrm{Zn}$ in Group III had a tendency to decrease with time, from $641 \mu \mathrm{g}$ after one week and $53 \mu \mathrm{g}, 8.3 \%$ of the initial concentration, after nine months.

There was a positive but not statistically significant coefficient of correlation 
$(\mathrm{r}=0.366)$ between $\mathrm{HOP}$ and $\mathrm{Zn}$ content in the zinc stearate groups. No relationship was found among the zinc stearate groups between the intensity of histological change and the $\mathrm{Zn}$ content of the lung.

\section{Discussion}

The fatal case of pneumoconiosis reported by Uotila et al. ${ }^{2}$ is a unique but important case of occupational lung disorder associated with exposure to zinc stearate, an organic metal. There is another interesting report of pulmonary fibrosis (complicated by encephalopathy) associated with the inhalation of aluminium dust which was coated with stearic acid, ${ }^{9}$ as a disorder due to a mixture of a metal and an organic substance.

However, it has been recognized generally that no fibrogenetic reaction is caused in the lung tissue by inhaled particles of $\mathrm{Zn}$ or $\mathrm{Zn}$ compounds. ${ }^{10)}$ The authors also observed that there was little fibrosis in the lungs of rats administered a mixture of $\mathrm{ZnO}$ and $\mathrm{MgO}{ }^{11)}$ Furthermore, an observation on toxicity of zinc stearate dust, contrasting with the case described in the Uotila's report, involved a fatal disease in a 57-year-old chemical worker in contact with zinc stearate powder from 1957 to 1969 , who showed normal $\mathrm{Zn}$ retention in the lung at the same level as in occupationally non-exposed persons, and was diagnosed as having pulmonary fibrosis of the Hamman-Rich type. ${ }^{12)}$ It was also indicated, in the same report, that inhalation of this powder at $5 \mathrm{mg} / \mathrm{m}^{3}$ for $3-5$ months did not cause any signs of fibrosis in rat lungs, although the exact procedure of the experiment and detailed histologic findings were not described. In another experimental study, Harding indicated that no fibrosis resulted from a single injection of $50-100 \mathrm{mg}$ of zinc stearate dust into the lungs or peritoneum of guinea pigs. ${ }^{13)}$ 'This was an important enquiry into the toxicity of this dust, but the results obtained seemed not to completely represent tissue reactions to the dust itself because of the somewhat inadequate design of the experiment as follows: an industrial material for rubber tires, not pure material, was used for the injection sample, and an extraordinarily high exposure dose, not appropriate to observe histologic reactions to such a bulky powder in the rat lung, was given.

From the above information about the toxicity of zinc stearate and related substances, it is questionable that the repeated inhalation or long-term deposition of zinc stearate was the only contributing factor in the development of fibrosis in Uotila's case, although some association might have existed. From this standpoint, the authors intended to duplicate Uotila's case experimentally and to observe the exact pathological changes in the lungs of rats that had inhaled zinc stearate dust.

In our experiment, zinc stearate dust suspended in $10 \%$ alcohol was administered intratracheally once into the lungs of rats. After nine months, rats were killed and pathological examination of the lungs was performed. The results were 
compared with those obtained by examining the lungs of rats administered quartz dust in the same amounts as the zinc stearate.

The amount of $\mathrm{Zn}$ retention during nine months was also determined. The $\mathrm{Zn}$ content of the control group, $80-110 \mu \mathrm{g} / \mathrm{g}$ (39-46 $\mu \mathrm{g}$ in whole lungs), was the same as that of normal rats reported by Hewitt et al. ${ }^{14)}$ In the $10-\mathrm{mg}$ zinc stearate group, the $\mathrm{Zn}$ content of the lungs increased soon after the administration, and then decreased rapidly. After nine months, the amount was found to be $8.3 \%$ of the initial amount. The course of $\mathrm{Zn}$ decrease indicates that the retention of zinc stearate dust in the rat lungs is less than that of quartz dust, and corresponds to Harding's observation ${ }^{13)}$ that zinc stearate disappears from the lungs of rats within about a fortnight, presumably by the processes of phagocytosis and solution. The course also shows that the pathological changes observed nine months after the administration of zinc stearate dust seem to correspond to the chronic effects of the dust at low concentration levels, not to the condition of accidental acute and/or repeated exposure to large amounts of this powder.

The lungs of rats administered $10 \mathrm{mg}$ of zinc stearate did not show any evident formation of dust foci or proliferation of collagen fibers after nine months, whereas such changes were evident in the rats administered $10 \mathrm{mg}$ of quartz.

The week fibrogenicity of zinc stearate dust was also demonstrated by the significantly lower levels of HOP in lung tissue than in the 10-mg quartz group which showed the same levels as in animals given $50 \mathrm{mg}$ of quartz particles with diameters of $7-10 \mu$ in Kyselá's investigation. ${ }^{15)}$ Acute inflammatory reactions following the intratracheal injection were not as obvious in the zinc stearate groups as in the quartz groups.

These observations indicate that the role of zinc stearate dust in the development of fibrosis or severe pneumonia may be quite small. However, in extraordinary situations, such as repeated exposure to a large amount of zinc stearate dust or exposure to the dust together with other fibrogenetic dusts in the work environment, it may play an important or main role in the development of the pathological changes as in Uotila's case. From this viewpoint, it seems to be incorrect to consider zinc stearate dust the only factor in the severe manifestations of pneumonia or pneumoconiosis, as stated in some manuals on the toxicity of industrial substances..$^{3,4)}$

From the above data on exposure to zinc stearate, it is appropriate to say, for the present, that zinc stearate should be categorized as a nuisanse dust with a recommended TLV of $10 \mathrm{mg} / \mathrm{m}^{3}$, and a STEL of $20 \mathrm{mg} / \mathrm{m}^{3}$ according to the ACGIH. ${ }^{16)}$

\section{ACKNOWLEDGEMENTS}

The authors wish to express our sincere thanks to Professor Hajime Miura, Kumamoto University, and Professor Toshio Matsushita, Kagoshima University, 
for their useful suggestions and comments.

\section{REFERENCES}

1) Murray, L. M. (1926). An analysis of sixty cases of drug poisoning, Arch. Pediat., 43, 193.

2) Uotila, U. and Noro, L. (1957). Lo stearato di zinco come cuasa di pneumoconiosis, Folia. Med., 40, 245.

3) Plunkett, E. R. (1976). Handbook of Industrial Toxicology, Chemical Publishing Co. Inc., New York.

4) Dreisbach, R. H. (1963). Zinc stearate, Handbook of Poisoning, 4th ed., p. 260, Lange Medical Publications (distributed by Maruzen Asia BTE Ltd., Singapore).

5) King, E. J., Mohanty, G. P. and Harrison, C. V. (1953). The action of flint of variable size injected at constant weight and constant surface into the lungs of rats, Brit. J. Industr. Med., 10, 76.

6) Stacy, B. D. and King, E. J. (1957). Die Bestimmung von Kollagen im fibrotischen Gewebe, Die Staublungenerkrankungen, Bd. 3, p. 189, Münster/Westf, Berlin.

7) Kivirikko, K. I., Laitinen, O. and Prokop, D. J. (1967). Modifications of a spec:fic assay for hydroxyproline in urine, Ann. Biochem., 19, 249.

8) Pharmaceutical Society of Japan (1980). Standard Methods of Analysis for Hygienic Chemist —With Commentary -, Kanehara Schuppan, Tokyo.

9) McLaulin, A. I. G., Kazantzis, G., King, E., Teare, D., Porter, R. J. and Owen, R. (1962). Pulmonary fibrosis and encephalopathy associated with the inhalation of aluminium dust, Brit. J. Industr. Med., 19, 249.

10) Browning, E. (1961). Zinc. Toxicity of Industrial Metals, p. 313, Butterworth, London.

11) Ueda, A. (1978). Studies on pathogenesis and prevention of pneumoconiosis due to sendo. III. Experimental studies on fibrogenesity to lung tissue due to "sendo" dust and to substitute materials for "sendo", J. Jpn. Assoc. Rural. Med., 27, 146.

12) Weber, J., Einbrodt, H. J. and Weber, B. (1976). Kann Zinkstearate eine Lungenfibrose auslösen? (Fallbericht), Beitr. Silikose-Forsh. (Pneumokon.), 28, 104.

13) Harding, H. E. (1958). Some enquiries into the toxicology of zinc stearate, Brit. J. Industr. Med., 15, 130.

14) Hewitt, P. J. and Hicks, R. (1973). An investigation of the effects of inhaled welding fume in the rat, Ann. Occup. Hyg., 16, 213.

15) Kyselá, B., Jiráková, D., Holuša, R. and Skoda, V. (1973). The influence of the size of quartz dust particles on the reaction of lung tissue, Ann. Occup. Hyg., 16, 103.

16) A.C.G.I.H. (1980). Documentation of the Threshold Limit Values, 4th ed., p. 447, Cincinnati. 